研究課題別研究評価

1. 研究課題名：分散実時間システムにおける時間概念の抽象化および形式化

2. 研究者名：田辺 誠

3. 研究の狙い:

実時間システムは「締め切りを守って」仕事をする必要があるため、そのプログラミングにおいては、 従来、保守性や可読性よりもどちらかというと実行効率に重点が置かれてきた。しかし、高性能なコン ピュータが安価に手にはいる現在、計算環境に余裕がある場合も少なくなく、その場合、コンピュータ よりも人にやさしいプログラミング環境を整備することが必要になる。すなわち、単に「速い」プログラ ムではなく、「時間の使い方についてよくわかっている」プログラムのための基礎理論が必要な時代が 来ると考えられる。本研究では、時間に関して我々が日常的に持っている自然な感覚に知恵を借り、 これらの形式化を目指すことにより、時間の持つさまざまな側面の抽象化を試みた。

\title{
4. 研究結果及び自己評価
}

研究結果: 時間の持ついくつかの側面を表現するための形式的体系を与えた。

1)資源としての時間: 実行時に消費される時間について見積もる際の操作と、線型論理における計 算資源に対する操作との類似性に着目し、線型論理を拡張し、時相線型論理体系を構築した。また、 この体系と並列実時間計算モデルである時間ペトリネットとの関連について研究し、体系の論理式が、 時間ペトリネットの遷移に関する仕様記述に、シークェントが仕様の変換に、シークェントの導出が、 仕様を満たす遷移の導出に、それぞれ対応することがわかった。

2)「証拠」としての時間: 直観主義論理においては、構成的な証明を持つ論理式のみが「正しい」と考 えられる。すなわち、具体的な証拠を持つ言明のみを真であるとするのである。本研究では、エラ一検 知におけるログと直観主義体系(に時間的拡張を施したもの)との関連付けを行なった。まず、エラ一 パターンの表現形式を考案し(時間イベントパターン)、このパターンの意味論が直観主議時相論理の 意味論と深く関係していることを示した。

3)複数の流れを持つ時間:実時間計算は、一般に複数のプロセスが並列に動作することによって行な われる。複数品目のレシピからなる料理や、ポーズボタンを押される可能性のあるゲームを例として 考えると、それぞれの仕様を記述する際に意識する時間の流れは、実際の物理的な時間の流れとは 異なる。本研究では、時間と資源の関係を表すプロセス代数 ACSR を拡張し、プロセスが独立した時 間軸を持ち、かつ、それぞれプロセスの持つ時間軸同士が緩やかに関連づけられる体系について考 察を行なった。

\section{自己評価}

それぞれの理論的成果を個別に評価すると、それぞれが時間の持つ特徵に対する知見を与えてく れたと考えている。特に、時相線型論理と時間ペトリネットの関連に関しては、研究当初は、論理式は ペトリネットの計算途中の状態に、シークェントは状態遷移に対応すると考えていたが、研究が進むに つれ、この予想とは異なる対応関係が発見された。また、直観主義時相論理とエラーログとの関係に ついては、エラ一が起こったことの具体的な証拠物(ログ)に対応する論理式を二重否定すると、「エラ 一が起こった」という状態記述に対応する論理式に変わることを、興味深く感じた。 
しかしながら、研究構想時には、これらの「各論」を比較·分類するための「総論」的な形式体系を作 ることを将来目標にかかげていたが、着手に至らなかった(正確には、いくつかの方向からアプローチ を試みたが、鉱脈を堀りあてるに至らなかった)ことが残念である。実際のプログラミングに応用するこ とを考えると、着目する側面によってプログラミング環境を変えることはナンセンスであるので、一つの 体系によってさまざまな側面を表現することが必要となる。これについては、それぞれの表現の複雑 度を小さくするエ夫と共に今後の課題として挙げられる。

5. 領域総括の見解:

これまで研究の進んでいなかった時間計算モデルの研究に取り組み、時相線形論理、直観主義時 相論理、実時間計算用プロセス代数等さまざまな論理体系を拡張して時間計算の新しいモデルの構 築とスケジューリングへの応用に成功した。特に、新しい時相線形論理体系の定式化を行なうととも に、その体系とペトリネットモデルとの論理的関係づけに成功したことは、今後の時間計算モデル研 究に大きな影響を与えるものと考えられる。

第1期生の研究期間における田辺誠の研究で特に注目されるのは、他の研究者がどちらかといえ ば実際にシステムの設計や実装を指向していたのに対して、当初は実際に十分な成果が挙がるかど うか懸念した領域アドバイザーもいた中で理論研究を着実かつ誠実に進め、大変充実した結果を出し たことである。このことは、さきがけ研究21の趣旨である独立した研究者の育成という観点からきわ めて高く評価できるものである。当初の計画に含まれていた時間論理の統合的体系を生み出すこと は困難なまま研究期間が終了したが、個別の成果としては十分な結果を出すことができたと高く評価 できる。

田辺誠が今後、わが国では研究者層の薄い理論的コンピュータ科学研究者として、この3年間の成 果と経験を生かし、時間計算のみならずさまざまな理論的テーマにおいて、わが国をリードする研究 者としてさらに充実した活動をしていくことを願つている。

\section{6. 主な論文等：}

·泉田 大宗, 川勝 則孝, 田辺 誠, 中島 玲二, and 林 良生. 時間イベントパターン.

コンピュータソフトウェア, Vol.17, No.5 (2000)

·泉田 大宗, 川勝 則孝, 田辺 誠, 中島 玲二, and 林 良生.

Recognizing timed event sequences -- formalism, machines and

applications -- (extended abstract).日本ソフトウェア科学会第 15 回大会 (1998)

参考論文

-M.Tanabe. Media object semantics for temporal linear logic.

MMM'97, the 4th International Conference of MultiMedia

Modeling. World Scientific (1997)

他 口頭発表 3 件 